Already museum staffs are engaged in various programmes of assistance to underdeveloped countries. If financial and organizational help were forthcoming there is no doubt about the willing co-operation which would be offered in collecting scientific and technological material for the museums which will be established in developing territories. Initiative at Government-level would appear to be an essential first step. JAMES GRET:

\title{
SEARCH FOR OIL AND GAS POOLS BENEATH THE NORTH SEA
}

$\mathrm{O}$ FFSHORE drilling for oil within continental shelf deposits has for some years past been established procedure in determining seaward extensions of proved land-based oil and gas fields, notably in the United States. The great advances in design, construction and adaptability of modern drilling 'barges' has made such projects economically feasible if not always commercially successful. So far as the United Kingdom is concorned, offshore drilling history was made in the autumn of 1963 by the first exploratory well put down $2 \frac{1}{2}$ miles off the coast at Lulworth Cove, Dorset, in this case using a self-elevating mobile De Long barge, in $60 \mathrm{ft}$. of water. The pioneers of this venture were the British Petroleum Company, who have also been granted permission by the Dutch Government to search for oil and gas in the Wadden Zee area off the northern Dutch coast.

Geologists in Britain, as in other West European countries bordering the North Sea, have long realized the possibilities of oil or gas pools (or both) existing in the sedimentary deposits constituting its floor, but by general consent the chances of locating commercially worthwhile supplies were not rated very high. This vista was, however, rapidly changed by the recent discovery and development of a major gasfield in the Groningen area in the Netherlands (Nature, 200, 123; 1963), the seaward extension of which is now the objective of great activity by various international oil interests. Prior to this, however, interest in the potentialities of the North Sea shelf off Britain was roused in 1961 when the British Petroleum, Esso and Shell Companies announced the start of a joint seismic survey of 30,000 square miles of the North Sea basin. Many ships carrying out such surveys, from Lowestoft to the Firth of Forth, have since been operative, under direction of the Shell Com. pany of the United Kingdom, Ltd., employing contractors. "This autumn, the experts in Bataafse Internationale Petroleum's Exploration and Production Division in The Hague should have in their hands a reasonably comprehensive picture of this stretch of the North Sea floor; it will have cost some half a million pounds to obtain but will provide the essential basis for a decision on where to continue seismic work or whether to start underwater drilling, and if so, where" (Search in the North Sea, Information Circular No. 40, Shell International Petroleum Co., Ltd., London; October, 1963). Other geophysical surveys have been in progress within a 20,000 square mile area off the coasts of Yorkshire, Lincolnshire and Norfolk, under the ægis of Pan American International Exploration Co., in association with the British Gas Council and some other American companies. The French
State concern BRP, through its British subsidiary, Coastal Oil, has been working an area of some 180 square miles within British territorial waters off the Yorkshire coast, and also carrying out seismic surveys in other parts of the North Sea.

Apart from the exploratory work off the east coast of Britain, Shell and Esso Companies (through a joint organization known as NA.M, that is, Nederlandse Aardolie Mij.), who were responsible for the gas discoveries in Holland, have been operating off the Dutch coast, both north and west; in the latter zone four offshore wells were drilled in 1961-62 at a total cost of $f 1.4$ million. In 1963 an extensive programme of seismic surveying within and beyond Dutch territorial waters was prosecuted. The net has, however, been spread much further recently, embrac. ing Scandinavian and Danish seaboards. In Norwegian waters Shell, Esso and British Petroleum group have conducted surveys; Phillips Petroleum, also the French concerns BRP and RAP have been active here. In Denmark, A. P. Møller, the shipowner, has obtained a 50-year exploration concession covering the whole country including Danish territorial waters; he, together with Gulf Oil Company (U.S A.) and Shell, are undertaking joint exploration in this region. Offshore developments in Germany are being sponsored by certain German oilproducing companies in which Pan-American oil interests are active.

Thus in the West European region of the North Sea basin the problems of North Sea oil and gas pools are well on their way to solution. According to the Shell Information Circular No. 40: "The surveys may show structures that might contain oil or gas but they may well prove to be empty; or oil may be present there but the first holes drilled may miss it. Fven if there were a show of gas or oil, it would be some considerable time before a suffieient number of exploration wells could be drilled for the companies to be able to determine whether or not they had discovered really significant reserves on Western Europe's doorstep". Oil and gas are not the only problems raised should commercial success reward these efforts of the oil companies; there may ensue interminable arguments on the question of who owns the mineral (including oil and gas) rights over the bottom of the North Sea. Some guidance on the legal aspects of this problem is provided by the Intermational Convention on offshore rights, drawn up by the Geneva Conference on the Law of the Sea in 1958; but so far, except for Denmark, none of the countries bordering the North Sea have ratified the convention and much internal legislation is likely before they do so.

H. B. MTINER

\section{POTATO RESEARCH IN BRITAIN}

ARGELY as the result of amendments to the Potato
Marketing Seheme, the Potato Marketing Board can
now increase its contribution towards research and assist
attempts to answer some of the problems facing the indus.
try to-day. To help it to do this, the Board has set up a
Research and Development Committee to advise on ways
in which research on potatoes can be encouraged and
assisted. In addition to the chairman, Mr. J. E. Rennie,
and six other members of the Board, who represent the intorests of the potato growers, the Committee consists of F. C. Bawden (director of Rothamsted Experimental Station), W. H. Cashmore (director of the National Institute of Agricultural Engineering), F. R. Horne (director of the National Institute of Agricultural Botany), Prof. Alexander Robertson (Agricultural Research Council), Prof. S. J. Watson (Edinburgh School of Agriculture) and Prof. W. T. Williams (University of Southampton). Dr. E. E. Cheesman provides the necessary liaison with 
the Agricultural Research Council. The Research and Development Committee is eharged with the duty of considering all aspects of research into potato production, processing and marketing, and of recommending to the Board new investigations or desirable extensions of existing research which it considers should be undertaken.

As a first step in assessing the problems to be considered. a survey has been made of the research and development work at present being done on potatoes at more than fifty universities and research centres in Britain. Broadly speaking, the main problems facing the industry to-day are: how to assess and maintain quality to meet consumer requirements; how to deal economically with potatoes surplus to human consumption in a year of excess production; and how to stabilize yields.

Certainly quality is of the utmost importance and it needs to be considered in relation to the specialized requirements of different kinds of consumer. The pattern of consumption is changing, but of the roughly $200 \mathrm{lb}$. of potatoes consumed per head of the population in Britain. 70 per cent is still prepared and eaten in the home. of the remainder it is estimated that approximately 15 per cent is used by caterers, 7 per cent by fish and ehip fryers. 4 per cent for the manufacture of crisps and 3 per cent for frozen chips, canned foods, soups and dehydrated products of various kinds. The housewife is, therefore, by far the biggest user of potatoes in Britain and it is important that the quality of the sample she is offered should improve, for as the competition from other foods becomes greater she may buy fewer potatoes.

Much research has been done on the factors that influence yields but much less on quality, probably because quality is very difficult to evaluate scientifieally. More research, therefore, must be directed towards devising physical and ehemical methods to assess quality and to integrate these measurements with taste-panel assess. ments. When these methods have been developed the factors that influence quality will become more amenable to exact study. This is a big problem, for it involves a consideration of almost all aspects of potato research and development, from the breeding of varieties to how fertilizers, agronomic practices and conditions of storage affect the suitability of the potato for its ultimate use.

The demand for better-dressed ware and the increase of pre-packaging, for which a high-quality product is needed, will incvitably lead to more potatoes being rejected for the table because of irregular shape, blemishes or mechanical damage. Methods of avoiding these sub-standard tubers, or finding an economic use for them, are urgently needed.

The third problem is set by the fact that potato yields differ greatly in different years while consumption is relatively static. These fluctuations in production cornplicate marketing, and until some economic way of using surpluses for industrial purposes can be found, stable yields from season to season may be more important than maximum yields. Stabilized yields are most likely to come from combining all those techniques that counteract the effects of the season on the growth of the crop, for example, sprouting of seed, correct manuring, and pest and disease control. Much researeh is now being done on these problems, but the Board would like to see much more.

The Board now assists research on potatoes by the following methods:

(1) Grants to universities and research stations to enable investigators to employ scientific, laboratory and other staff to work on a particular research project; to obtain special apparatus and/or equipment and to provide materials and services specially needed for the research.

(2) Postgraduate studentship awards to graduates holding first- or upper-second-class honours degrees. These awards aro at present worth $£ 600$ per annum, tax free, plus fees, and are tenable for a maximum period of three years at a selected university or research station approved by the Board.
On the recommendation of the Board's Research and Development Committee the following grants have so far been awarded:

(1) Dr. E. C. Bate-Smith (Low Temperature Research Station) (2 grants), (i) for an investigation of the fundamental biochemical and histological factors involved in the texture of the potato; (ii) to investigate the structure and the factors influencing the formation of the phenolic constituents of plants.

(2) Prof. H. Godwin (University of Cambridge), to investigate the factors which determine the sugar content of potatoes.

(3) Prof. E. S. Hallsworth (University of Nottingham). for an investigation into the biochemical processes within the plant that influence the growth and quality of potatoes particularly in relation to their quality for crisp manufacturers and resistance to damage.

(4) Dr. J. M. Hirst (Rothamsted Experimental Station). for an investigation on the phenology of skinspot, common scab and other potato tuber blemishing diseases.

(5) Dr. E. C. Humphries (Rothamsted Experimenlal Station), to investigate the part played by different plant growth regulating and inhibitor substances in controlling dormancy and sprouting in the potato tuber.

(6) Mr. F. R. Horne (The National Institute of Agricul. tural Botany), to investigate further the factors that influence the cooking quality of potatoes with particular reference to their texture and tendency to disintegrate when boiled.

(7) Prof. J. D. Ivins (University of Nottingham), to study the effects of fertilizers and irrigation on both early and mainerop potatoes with particular regard both to the time of application of these treatments in relation to the growth, development and quality of the crop, and to the maturity and susceptibility of the tuber to damage during harvesting and handling.

(8) Prof. F. L. Milthorpe (University of Nottingham) (2 grants), (i) for an investigation of sprout growth and apieal dominance in the tuber; (ii) for further studies on the varietal and environmental factors that influence the infection of potato sprouts by Rhizoctonia solani.

(9) Mr. J. W. Slater (Agricultural Research Council Farm Buildings Unit), to investigate the effects of variation in temperature and light in different parts of ehitting houses and potato stores on the physiology of seed and ware potatoes.

(10) Prof. S. J. Watson (The Edinburgh School of Agriculture) (2 grants), (i) to investigate the biology, feeding habits and means of control of the common species of slugs that cause damage to potato crops; (ii) for an investigation on the husbandry factors that influence the yield and proportion of seed-sized tubers in seed potato crops.

(11) Dr. C. L. Cutting (British Food Manufacturing Industries Research Association), for an investigation of methods for the prevention of discoloration in raw pecled potatoes.

(12) Prof. J. Yudkin (Queen Elizabeth College, University of London), a contribution to the work on an investigation into the social aspects of nutrition.

(13) Arthur D. Little Inc., to conduet an enquiry into the possibilities of the industrial utilization of surplus potatoes in Britain.

In addition to these research grants, postgraduate studentships have been awarded to Miss D. Glendinning (Scottish Horticultural Research Institute), Mr. P. H. Lovell (University of Sheffield), Mr. P. Hunter (Agricultural Research Council Unit of Insect Physiology). Mr. P. W. Dyson (Rothamsted Experimental Station) and Mr. A. R. Procter (University of Edinburgh).

Notices about the research grants and postgraduate studentships awards are usually circulated in February and applications for 1964 should be received by the Board (50, Hans Crescent, London, S.W.1) not later than March 31 .

C. I. HAMPSON 